Correction

\title{
Correction: Kotali, A. 1-(o-Hydroxyphenyl)-3-phenylpropenone $N$-benzoylhydrazone. Molbank 2003, M350.
}

\section{Antigoni Kotali}

Laboratory of Organic Chemistry, Department of Chemical Engineering, University of Thessaloniki, Thessaloniki 54124, Greece; E-mail: kotali@eng.auth.gr

Received: 28 January 2009 / Published: 26 February 2009

We found the following error in our paper published in Molbank a few years ago [1]. The correct title should be: 2,2'-Dihydroxybenzophenone $N$-Carbonylethoxyhydrazone.

\section{References and Notes}

1. Kotali, A. 1-(o-Hydroxyphenyl)-3-phenylpropenone N-Benzoylhydrazone. Molbank 2003, M350.

(C) 2009 by the authors; licensee Molecular Diversity Preservation International, Basel, Switzerland. This article is an open-access article distributed under the terms and conditions of the Creative Commons Attribution license (http://creativecommons.org/licenses/by/3.0/). 